\title{
Pituitary Gland Diffuse Large B-Cell Lymphoma
}

National Cancer Institute

\section{Source}

National Cancer Institute. Pituitary Gland Diffuse Large B-Cell Lymphoma. NCI

Thesaurus. Code C155797.

A rare diffuse large B-cell lymphoma that arises from the pituitary gland. 